\title{
GETTING LOST TO BE FOUND: THE INSIDER-OUTSIDER PARADOXES IN RELATIONAL ETHNOGRAPHY
}

\author{
Roland K. Yeo \\ Saudi Aramco, Saudi Arabia, and \\ University of South Australia, Australia \\ Email: roland.yeo@unisa.edu.au \\ Sue Dopson \\ Saïd Business School \\ University of Oxford, United Kingdom \\ Email: Sue.Dopson@sbs.ox.ac.uk
}

\section{Acknowledgments}

We found the in-depth and constructive feedback of two anonymous reviewers to be inspiring and helpful, helping us to reshape the paper with additional data and analysis. We hope this paper will inspire more collaborative endeavors between practitioners and academics in developing scholastic practice-based research. 


\begin{abstract}
Purpose:

The paper draws on the direct experience of a practitioner undertaking real-time research in his organization to offer insights into the dual role of practical insider and theoretical outsider. The duality helps the researcher to live 'in' and think 'out' of the research context to develop a theory for practice and then transpose it to a practice for theory through the collaboration of an external theoretical insider.

Design/Methodology/Approach:

This is a theoretical account of the reflexive experience of the practitioner reintroducing relational ethnography, where the researcher regards processes and spaces as the objects of analysis rather than bounded groups and places. It emphasizes the relational significance of the researcher, researched, and theoretical insider in exploring the structures of relations and meanings in the field of professional practice.
\end{abstract}

Findings:

The paper argues that understanding the complementariness and paradoxes of the dual role helps the researcher to identify knowledge gaps and contest commonsense knowledge in search of critical knowledge and theoretical insights. Transition between the bounded (restrained) and unbounded (unrestrained) selves occurs in the holding space of research, influencing the position from which the researcher views himself, his subjects, and his social world.

Originality/Value:

The paper extends the dimension of ethnographic research, which de-centers the authority and control of the researcher to that of the relationship between the researcher and informants, by focusing on the relational significance between the researcher, researched, and theoretical insider. This perspective gives rise to a deeper understanding of relational 
ethnography, seen largely in sociological research, as relevant to organizational research, where structures of relations and actions explored in real-time could account for the configuration, conflict, and coordination of work practices.

Keywords: Duality of researcher, relational ethnography, holding space, research paradoxes, practitioner-academic collaboration 


\section{INTRODUCTION}

Qualitative research requires that researchers explore the breadth and depth of phenomena by being involved in the experience of particular informants and the context within which such phenomena manifest themselves (Stainback and Stainback, 1988). As opposed to practitioner-researchers, mainstream researchers conduct studies without being deeply embedded in the research context as an inside member. Hence, they face the challenge of retelling and making sense of others' experiences (or narratives) through their own interpretation of those experiences (Desmond, 2014). Ensuring the reliability of qualitative data is both a challenge and an opportunity for any interpretive researcher to make deeper sense of the ensuing phenomena (Gioia and Chittipeddi, 1991; Yin, 1981).

This paper provides fresh insight into the research process of the first author, who is a practitioner, from an insider perspective while achieving theoretical rigor by co-constructing the narratives of others through the collaboration of an outsider. In this context, the practitioner is referred to as the practical insider and the collaborator as the theoretical insider. The practical insider recognizes the tension that comes with the dual role of being a practical insider and a theoretical outsider. Such tension is problematic on several levels, as it overstretches the understanding and interpretation of what is actually occurring in the minds of the informants, the moment of practice, and not least the relevance of practice to theory and vice versa. Reflecting on this intertextual experience - that is, experience embedded in the multi-voices of informants and unfolding practices of the organization - the paper proposes a relational approach to research collaboration by raising the question: How can a researcher negotiate the insider-outsider paradox to translate theory for practice into practice for theory using relational ethnography? In other words, how can a researcher draw on actual practice - that is knowledge of professional practice performed by individuals - to produce theoretically-relevant knowledge? More crucially, this paper argues for the position 
of theory as being reproduced or contested by practice seen in relational ethnographic research, rather than the position of theory as being reinforced or elaborated in practice seen in most qualitative research (Islam, 2015). Using practice to theorize reveals hidden critiques of theory which could lead to a wider discovery of theoretical boundaries (Boltanski, 2011).

\section{Response to collaborative research between practitioners and academics}

This paper further responds to the call for celebrating qualitative research as a craft through the constant sharpening of skills where the insider-outsider researcher interprets found critiques or critical knowledge arising from multiple voices within the research context (Cunliffe and Locke, 2015). The paper also attests to the importance of harnessing the support of the qualitative research community through collaborative inquiry (Clark and Sousa, 2017). The co-author, who is an academic and a theoretical insider, bridges the insider-outsider paradox by helping to push theoretical boundaries in order to gain a deeper understanding of theoretical divergences. Such collaboration reinforces the methodological significance of relational ethnography, where both researchers work towards negotiating the insider-outsider paradox as a means of establishing practical and theoretical insights into a particular research context.

The paper is motivated by a need for practitioners to collaborate with academics to jointly explore the depth and richness of qualitative research. While the practical insider has the privilege of gathering firsthand, real-time data in the workplace, the theoretical insider can offer theoretical insights to help the practitioner make better sense of the unfolding data. Although their roles may complement and contradict each other in terms of research priorities, their relational experience facilitates a deeper level of dialogue both in and between themselves.

The practitioner translated his intimate relational experience with his colleagues, also his subjects, into reflective narratives in an attempt to make sense of their position and 
interest in the researched. On the other hand, the external academic used the narratives as boundary objects to help her understand the underlying conditions of people's cognitive and behavioral response to certain situations. Intensifying the relational experience, the academic challenged the practitioner to internalize the data by first understanding the position (above the surface) and interest (beneath the surface) in the research process before interpreting the data at a much deeper level. In essence, the academic helped the practitioner to see what others see in his own perspective through sharp questioning and sensebreaking. This process allowed the practitioner to distance himself from the data in order to reengage with his data. The academic identified intersections of paradoxes and similarities between the practitioner and his subjects, taking his trajectory of contextual understanding to another level. The aim was to allow the practitioner to recognize what was not detected in those intersections, particularly what people said they would do (enacted behavior) versus what they actually did (authentic behavior). Through an iterative process of critiques of the reflective narratives and deep conversations, they developed a collaborative discourse offering the depth and richness of qualitative research in achieving both practical and theoretical insights.

\section{Extending relational ethnography}

In recent times, relational ethnography has begun to receive some attention in social practice with Simon (2012) and Desmond (2014) reporting on different aspects of research orientation. Simon's (2012) focus on the relations of reading and writing in the field of communication lends credence to harnessing the different voices of the researcher; the inner and outer dialogue between the researcher and others calls for "a new array of collaborative, polyvocal, and selfreflexive methodologies" (Gergen and Gergen, 2002, p.13), building on relationality as a research process. On the other hand, Desmond's (2014) social perspective of action coordination and trajectories of practice across fields emphasizes relationality as "object configurations of connections, transactions, and unfolding relations" (p. 574). Both 
these perspectives are pertinent in organizational research where the locus of practice is shifted to the profession of work practice instead of institutional practice. This paper contributes to current literature on relational ethnography in three ways.

First, it argues for a psychodynamic position where research is deemed a holding space for researchers to make sense of what is 'up' there (theory) and 'down' here (practice) in a relational way (Trist and Bamforth, 1951). Psychodynamics refers to the way in which we develop frames of references as we interpret external objects by modifying our mental and behavioral patterns to make sense of our experience (Azmatullah, 2014). The concept of holding space suggests that we leap out of our routine into a psychological space where we come to terms with our dilemmas and paradoxes in order to make sense of the social world (Petriglieri and Petriglieri, 2010; Winnicott, 1986).

Second, the paper offers an alternative perspective of relational ethnography where practice is experienced 'on' the ground in an organization constituting a field of professional practice rather than different fields of institutional practice (Desmond, 2014). The micro-level of human interaction within a particular field could arguably form the basis of theoretical contestation and revision through the interplay of insider and outsider roles. This perspective emphasizes theory as being in the background and foreground of practice mediated by practical wisdom through practical insiders (Gioia et al., 2013).

Third, the paper offers deeper insight into the paradox of the dual role of a practitioner as he experienced firsthand the challenge of negotiating his theoretical outsider and practical insider position when conducting research in his organization. The practitioner had to grasp the dialogical relationship between theory and practice by attaching to and detaching from the perspective of living 'in' it. The dialogic expectation is complex as it assumes that all interactions are dynamic and relational to that extent that the social world is constantly being re-described (Bakhtin, 1981). 


\section{RESEARCHING FROM GROUND UP}

Qualitative researchers seek a variety of methodological approaches to understand the mental representations of people and how these relate to their lived and perceived experience in a particular context (Bogdan and Biklen, 1992). Often times, researchers gain entry into such experience by interviewing individuals or groups and/or observing certain activities, such as meetings, shop floors, or even daily routines. In this paper, we extend the perspective of relational ethnography (Desmond, 2014) by drawing on the personal, firsthand experience of the first author (practitioner) functioning as a relational conduit between his researcher and employee roles.

As a methodological lens, relational ethnography is particularly relevant for practitioner-researchers seeking to apply their knowledge of a certain theory to their own professional practice. The ultimate challenge is not to seek a balance between the position of practical insider and theoretical outsider but rather the relational complexity of transitioning between the two positions (Gergen and Gergen, 2002). Such ethnographic orientation shifts the focus from a researcher's observation and interpretation of the social world to that of the interactional dynamics between the researcher and informants (Islam, 2015). The dynamics reveal the role of the researcher and informants, particularly the way the roles interpenetrate each other (Van Maanen, 1979). Relational ethnography suggests the researcher living 'in' and studies the very phenomena of an organization and participating in the coproduction of discourses by drawing out actor-produced perspectives to explore pseudo theories (Webe et al., 2001). This is where the researcher plays the dual role of practical insider and theoretical outsider to create new dynamics with local informants to jointly understand the emerging phenomena that could offer insights into existing theories, shifting the object of research from 
bounded groups and places to processes and spaces from a relational perspective (Gergen, 2009).

In qualitative research, the premise that theory can learn from practice stems from the recognition that informants function as theoretical sources. In other words, by engaging in the experiential world of informants, researchers can help coproduce knowledge that reveals not only individuals but also the organization to which they belong. Researchers could capitalize on the knowledgeability of informants to gain deeper understandings of what characterizes organizing and organization (Gioia et al., 2010). As knowledge agents, informants are capable of articulating particular meanings, organize them around particular logics, and enact organization patterns that shape particular practice. Understanding informants' struggles and tensions in organizations helps researchers see alternative cognitive and behavioral patterns which, in turn, shape context and practice (Clegg et al., 2005). Often times what happens 'on' the ground is an explicit contestation of theory that is often times conceptualized 'off' the ground at a more abstract level. The practical insider is, thus, placed in a unique position to experience real-time contestations, conflicts, and contradictions occurring in practice.

Being 'on' the ground is crucial for research and can potentially be achieved through a quasi-peer relationship between a practitioner and an academic. In this paper, such relationship taps into the practitioner's role as he has optimal access to his informants' subtle processes of theorizing by collaboratively contesting, modifying, and developing their institutionalized and technical knowledge (Kempster and Stewart, 2010). Corley (2015) referred to such collaboration as engaging a phenomenon from the perspective of those living 'in' it, especially the practical insider. Not only does the practitioner live 'in' a particular context but he also co-constructs meanings and symbolic representations of organizations with his colleagues using a constructivist epistemology (Fawcett and Hearn, 2004). Being 'on' the ground and living 'in' it allows the practitioner to theorize through new experience 
as he gathers data to reshape conventional theory with subsequent input from his co-author, the theoretical insider. In particular, this paper describes how informants - including the practitioner as an employee - develop varying degrees of critiques that contest the limitations of institutionalized actions representing their professional practice. Simply put, the practitioner is positioned to experience how employees attempt to unlearn their conventional wisdom of practice. In what follows, the paper draws on the authors' collaborative experience by way of reintroducing relational ethnography. In particular, it will describe the opportunities and constraints experienced in data gathering involving real-time observations and interviewing, and collaborative theorizing between them representing the practitioneracademic synergy.

\section{THE RESEARCHER'S PARADOXES AND RELATIONAL EXPERIENCE}

The practitioner wrote a series of reflective essays around the various aspects of the research to articulate his views, thoughts, and experiences in trying to establish a close relationship with his research and data. This was for him a dialogic process as he developed a conversation with himself while expressing his practical theorization. Practical theorization involves the sensemaking of his personal paradoxes as both an employee and a researcher (Weick et al., 2015). The following is an account of how he negotiated his paradoxes at three different stages of the research, a summary of which is presented in Table I.

$===$ Take in Table I near here===

\section{Entry: Accepting and challenging prior knowledge}

There were different relational turns that created subtle shifts in the way the practitioner perceived and understood the unfolding phenomena, often constrained by prior knowledge at the point of entry into fieldwork. For example, ethical considerations came into play prior to engaging in deep interactions with his colleagues, who were also his research informants, 
helping him frame the reality of their social world. Hence, he was cautious about not pushing the relational boundaries to learn about the thinking and behavioral patterns of others. This led to his bounded self holding back judgment about the assumptions others held of particular contexts and issues. The bounded self is an enacted voice projected to meet social expectations, as articulated in an extract from his reflective essays:

My view of the work environment is that it is characterized by silos without a strong culture of knowledge sharing and collaboration. I assume the large majority of employees accept status quo as being the norm. Not rocking the boat is a means of staying afloat and safe in the company. I want to have a deeper understanding of why the employees think and behave the way they are.

As a practical insider, he drew on his unbounded self and viewed the social world as it unfolded. The unbounded self is an authentic voice unconstrained by the multi-voices of the social world. In fact, he did not allow his preconceptions of the social world to affect his spontaneity towards his interactions with others. Instead, he regarded every informant as an individual with a personal voice through which to construct a compelling story. He recognized the need to be authentic in order to experience the unfolding activities and happenings in real time, motivating him to push relational boundaries even further. The following extract offers a glimpse of his unbounded voice:

My personal understanding of the employees is that they are individuals with a personal vision and values. Through a more personal way of interacting with people, I am aware of the paradoxes they are living in. For instance, they want to make a difference in an individual way but on the other, they tend to keep their heads down under corporate 'fire' so as not to be 'burned'. I want to listen to their hearts and understand their personal philosophy and principles that shape their work.

The paradox experienced by the practitioner as a researcher was that of identity versus belonging. The bounded self gravitated him towards his immediate work context to which he felt a sense of belonging, while his unbounded self reached out for the values to which he holds true based on his identity as an individual rather than merely an organizational member, as reflected in the following extract: 
My struggle is that I am living in a reality constructed by others. Being part of the culture and thinking of others makes me feel I belong here in some way. Yet, I also recognize the individual and deeper side of human being and work life. I do not want my personal identity to be compromised and be led by the nose of what others say about their reality. I struggle to find a balance between appreciating the norm and revealing the less obvious of how people think, feel, and act.

Consequently, the view undertaken by the bounded self of the social world is that it is constructed by the preconception of others based on what has been said or written about. On the other hand, the unbounded self would view the social world in relation to the unfolding of activities and happenings in real time giving rise to an emergent quality. Negotiating between the two personas was, nonetheless, a delicate balance for the practitioner in order to ensure that he did not compromise his personal identity and values while identifying with the general sentiments of others at the same time.

\section{Transition: Deploying relational turns during interviewing}

Switching between insider and outsider hats while conducting research was for the practitioner an ongoing unlearning and relearning experience, particularly when he transitioned into the process of data gathering. Relationally, his bounded self maintained a fundamental level of professional connection with his subjects often using common references, such as company policies, systems, rules, and expectations, as shared objects of workplace interest that shape their conversational boundaries. Focusing on references they were familiar with led to a less spontaneous approach to data gathering, an area he had to unlearn. The familiar would influence the researcher's objectivity by stereotyping his perceived reality of others into predictable patterns of certain expectations or assumptions. Sometimes, situated distancing from the context by challenging prior knowledge in the moment helped him reconnect with his subjects in a more emergent manner, an area he needed to relearn:

I wear the hat of a stranger trying to sniff out anything unusual that's not within my expected understanding of a situation or issue, like my colleagues' reaction to issues about culture or change in the company. Often times, being immersed in conversations with people who share 
largely similar (negative or positive) sentiments about the company has led to some synchronization of views influencing me to 'sing the same tunes' along with my colleagues. Long enough, this influence builds a dominant view of the reality even though I might have different thoughts about my environment and the people I work with.

The level of engagement became more intimate when he switched to his unbounded self by connecting with his subjects through his authentic persona. Relationally, spontaneity increased as he demonstrated vulnerability by revealing more of his emotions about issues surrounding the context. Reciprocally, the informants opened up to him by sharing deeper sentiments and concerns of particular contexts and allowing empathy to harness the relationship. He also found moments resonating with the dilemmas of others while helping them make sense of their dilemmas. More importantly, most informants regarded the interviews as a holding space to step back and view their social world with some clarity as they reconnected with their personal authentic voice:

I identify with others in terms of their dilemmas. I often feel 'we are in the same boat'. When employees are disgruntled, I ask what their vision of their job is. Some don't have a distinct vision and don't believe in one but still do a good job. Others believe in the vision of the company but do nothing about it. In my search for deeper voices, I want to listen to how employees' personal values or vision are challenged or superseded by culture or uncontested practices. I feel like a living organism bouncing ideas and feelings off of each other to understand what 'living in the moment' is all about to experience the tension of myself and others, and be spontaneous about my response to reality.

The paradox experienced by the practitioner was one of control versus connection in exercising discipline and spontaneity, relating with and learning about others. On the one hand, the bounded self gave him a sense of control over the data by grasping the predictability of how his colleagues would think, feel, and act in particular contexts. The shared expectations of the contextual attributes, such as organizational functions and policies, and the potential response of the employees to these attributes made him feel in control of the research process. On the other hand, the unbounded self struggled to find a middle ground when connecting with others in a more authentic manner, as encapsulated in an extract below: 
Finding ways to learn about how employees think, feel, and act requires both discipline and spontaneity. The feeling of being 'in the same boat' limits my propensity to discover the underlying thinking and behavior of others. Being too familiar with the environment reinforces my control over the responses I seek. On the other hand, I want to also connect with how I feel and how others feel about their ownership of and belief in their work and predominant work practices. I want to see possibilities of more distinct thinking and acting. My struggle is to understand how employees (including myself) demonstrate ownership of their work and at the same time reject values that run contrary to their work.

\section{Exit: Performing reflective sensemaking}

The dialogic process intensified when the practitioner took a different relational turn from his subjects to the objects of his research by engaging with his data as constructed through the narratives of his informants. Engaging in the messy data presented both opportunities and constraints in the way he made sense of the enacted and authentic behavior of his colleagues. The dual role of the researcher made his data interpretation complex and at times problematic. For instance, his bounded self used the data as a distancing device to relearn the objective reality of the social phenomena based on the narratives he helped coproduce during the interviews. One way of helping him view his data in perspective was to undertake a rationalist approach by treating the narratives as objects of social reality rather than subjects of social construction, as reflected in an extract below:

The stories I have gathered from others serve as boundary objects that help me understand the different facets of organizational reality, especially the way reality has been constructed based on views of the majority. These stories form the basis for refining the boundaries of how the organization is perceived and subsequently defined. It is as though I were collecting stories (data) to sharpen the image of the organization. There could be assumptions about the reality that have not been completely challenged.

Making sense of what was projected above the surface (enacted behavior) and beneath the surface (authentic behavior) of the data further revealed his paradoxical struggle. The practitioner had a relational significance with the data as he lived in and through it, a complex dimension intertwined with the narratives he socially constructed with others. In other words, he used the data as the source of his conversation to gain a deeper understanding of himself and his social world. Practicing reflective sensemaking was for him an authentic experience 
as he wanted to be truthful about the researcher himself and the researched. He then embarked on a more subjectivist approach to data interpretation by focusing on the intent of the projected voices rather than taking the narratives at face value. The following is an example of how he encouraged authentic relational turns by helping others frame their intent of their narratives and actions:

By opening up to talk about what is expected of one to perform and what one expects of oneself and others to perform is liberating. Such conversations have helped each other to reconnect with ourselves as individuals. As an insider, indirectly I want them to be more truthful about who they are - their role, position, and how they experience their world of work and what they would do to create a desired world of work. Therein lies a deeper voice of employees' self-worth and how they can make a real difference if they are not constrained by job description, position, or role.

Creating the relational possibilities offered him various moments to engage in personal talks that revealed subtexts about social phenomena, especially the unspoken rules and practices. These subtexts with which he could resonate, in turn, became the basis for data personalization as he lived in these subtexts (side talks) himself. However, because of the way reality and data were so intertwined, he experienced difficulty in objectifying the data. He could not distance himself from the data as he felt a very much part of the coproduction of data. The paradox was one of reliance on what was articulated and autonomy over what could be articulated.

Making sense of the data to identify the different voices of the subjects is challenging. While my outsider role motivates me to look at the similarities and differences between the thinking and behavior of employees, my insider role examines underlying thinking patterns that suggest enacted and genuine behavior. My struggle is not only a fundamental reliance on how the subjects articulate their assumptions and modify their behavior to accept or reject those assumptions, but also autonomy in challenging their assumptions to bring clarity about their enacted behavior, and genuine behavior.

Such paradoxical moments gave data interpretation a different dimension.

Interpretation of reality could be essentially based on how people make sense of their social world by identifying the relationship between their perceived and lived experience. Providing a deeper dimension, the interpretation of reality could be based on how people make sense of 
their inner and social world by identifying the relationship between their desired and lived experience.

\section{THE PRACTICAL INSIDER AND THEORETICAL INSIDER COLLABORATION}

The practitioner met up with the academic every two to three months over a period of 18 months and engaged in intense one-on-one conversations about the research. Additionally, they communicated through Skype, phone calls, and emails to discuss the data the practitioner had gathered. The academic acted as both a joint sensegiver and sensebreaker as she helped him appraise his data from an outsider perspective. Their conversations were largely grounded by sharp turns of inquiry surrounding the practitioner's paradoxical perspectives. As theoretical insider, the academic used the research paradoxes as points of entry to jolt his thinking, helping him not only to reconcile his constraints as a practitioner to appreciate deep theory but also unlock his tunnel vision to view his data as living, unfolding stories. The following is an account of how he used his narratives as boundary objects to provide entry points for the theoretical insider to critique and challenge his understanding of the data from the theoretical standpoint. Boundary objects are specific objects or abstract concepts used as interpretive devices to provide common frames of reference in a communication process to help establish shared understanding across different domains of knowledge and practice (Beckhy, 2003). Methodological implications are drawn from the practical-theoretical insider collaboration and presented in Table II.

$===$ Take in Table II near here===

\section{Clarifying the intersections of practitioner's paradoxes}

The role of a theoretical insider in practice-based research is crucial for offering a wider and deeper understanding of the theoretical gaps and contributions as represented in the data. In this context, the academic used the reflective essays of the practitioner as a point of inquiry to help him appreciate theoretical meaningfulness and relevance. As the practitioner writes: 
To better articulate my dual role research experience, I wrote a series of reflective essays each varying between 7,000 and 12,000 words. Each essay documents the development of my thoughts and relational experience with my subjects. In my faceto-face meetings with my co-author - the theoretician - she would construct a deep conversation around each essay to help me deconstruct my voices as insider and outsider as well as those of my subjects by asking sharp questions. Then, she would identify points of intersection and asked where the voices belong: assumptions, enacted behavior, or genuine behavior.

Not only did the academic probe for understanding through recursive questioning but she also helped the practitioner recognize the interdependencies and distinctness of his insider-outsider role. This enabled him to discover found critiques in practice which could have greater relevance to particular theoretical explanations. Consequently, she challenged him to think deeply of the researched as a practical insider but sense widely the social phenomena as a theoretical outsider. In doing so, she tried to understand very specific paradoxical moments and probed to identify points of intersection between these paradoxes. The academic further helped him internalize the conflict as a personal and relational experience, teasing out the intricacies of different relational turns. She did this by helping him shift his attention from what was going on in his mind about his understanding of the social phenomena to that of what he actually experienced during specific relational moments with his subjects. Focusing on concrete experiences helped him think more deeply about what was said, felt, and the subsequent actions taken. She highlighted specific statements in the essay to challenge his paradoxical struggles about being lost and found in his duality, such as the example below:

Often times I remind myself of my role in the company, that I have a voice to project, to command respect based on my position of influence, to be a distinct individual. At other times, I get immersed in the crowd and lost in a sea of unreal identities. I quickly become one of them using the same language of complacency.

In short, using the reflective essays as another layer of data interpretation helped the practitioner make deeper sense of his duality which gave greater meaning to and understanding of the raw data. Collaborative inquiry and critique through the involvement of 
a theoretical insider further afforded him the experience of a different relational turn to recognize and articulate his paradoxes as potential enablers of in-depth qualitative research.

\section{Dialoguing by engaging in relational discourse}

Another role of the theoretical insider was to help the practitioner develop a conversation with his data by appreciating data as a living discourse. Simply put, the reflective essays were used as a distancing device to construct relational discourse for the practitioner. This helped him critique his own reflections of his duality and relational experiences during the research process through the help of a theoretical insider. In turn, the theoretical insider took a step further to critique his critique in order to reveal underlying issues about the social phenomena surrounding the researched that would otherwise have not been considered. The two-way critique was for him a dialogic process, one that created different possibilities through the interactional dynamics, as exemplified in the following extract:

When my understanding of people and their response to the social world becomes complex, I use writing as a tool to help me connect back to what people think and feel what they say in order to safeguard myself from jumping into conclusions of I think they said. Allowing my theoretical insider (co-author) to critique my essays brings my understanding of the underlying issues to both a wider and deeper level.

The dialogic process helped the practitioner develop a heightened awareness of how he could capitalize on his paradoxes to gain clarity in order to understand the cognition and behavior of his subjects. The tension between projecting an authentic voice and masking behind the dominant voice of others was also spilled over to his relationship with the theoretical insider, who used the extract below to jumpstart discussion about complex issues, such as "discomfort" and "comfort zone". In essence, the constant looping of feedback and critique facilitated by the theoretical insider helped him leap out of the comfort zone to articulate the research discomfort brought about by his paradoxical experiences.

As part of everyone else, I sometimes feel I should go with the flow and do what everyone else is doing; that is, keep busy, don't challenge status quo, follow protocol and be on the good side of people. It's easy to forget who I am when you are busy behaving like everyone else. Noticing people's discomfort in their comfort zone 
makes me realize another side of people's behavior. I have learned to be more aware of how people see themselves deep inside and how they feel when others see them.

In short, the theoretical insider's recursive critique and questioning helped him understand the importance of contextual dissecting in order to reengage the data from different divergent perspectives. Rewriting real-time data into reflective accounts further helped the practitioner to both personalize and objectify the information. But it was the theoretical insider who helped him shift the vantage point of the social world in the way he deconstructed and reconstructed his reflective narratives. More importantly, the relational experience between the practitioner and academic served as a reflective activity in discovering the position (generally-accepted perceptions) and interest (unspoken nuances) emerging from the data.

\section{Making deeper sense of positional dilemmas through sensebreaking}

Playing dual role sometimes led to unintended consequences in the research process for the practitioner. For instance, reflective writing served as a sensebreaking device to go beyond the surface of the data by considering alternative perspectives based on the positional standpoint of each role. Sensebreaking is a process by which a person creates a mental shift to provide a void in meaning of a referent point previously familiar to the other person in order to help him or her think of alternative perspectives (Gioia and Chittipeddi, 1991). Writing down the paradoxical challenges helped him break away from the assumptions of any expected cognitive and behavioral patterns as he considered other deviances arising from complex contextual influences. Using the following extract as a sensebreaker, the theoretical insider nudged him to think about his subjects' response to his reflective accounts and determine if the response might create alternative relational nuances.

Writing down my data in the form of narrative in the way I construct it helps me understand the different levels at which people operate when they respond to their work and environment. Having deep conversations with a theoretical insider about the 
discourse often times challenges me to think of myself in the shoes of others. I then

relate myself in and to the voices of others.

The theoretical insider further used wider sensebreaking techniques to help him both appreciate and distance from his positional dilemmas. As an example, the theoretical insider used a reverse logic to call out the authentic response to modeling a negative behavior rather than a positive behavior in his research execution. This actually forced the practitioner to think about the unanticipated impact of his relationship with others in order to make deeper sense of his intent and enacted behavior, as reflected in the following extract:

I sometimes feel I can steer the course of conversations in my workplace by reframing issues and shaping agendas. I think I can change people's mindset by helping them model positive behaviors. But at the same time I fall into the trap of wanting to be like the rest of the employees, maintaining status quo as an accepted norm. When I merge with the rest, I look at things on the surface forgetting about what is beneath.

In short, the relational experience between the theoretical insider and practitioner helped him to sharply question the emerging data while adding greater contextual textures to his reflective accounts. In doing so, he became more aware of the motivations behind the enacted and authentic behaviors of himself and others. The use of sensebreaking devices through reflective writing and external critique through the help of a theoretical insider helped the practitioner reconstruct his assumptions to give new meaning to his raw data.

\section{A MODEL OF THE INSIDER-OUTSIDER RESEARCH INQUIRY}

The deeper reflection of the practitioner-academic collaboration has led to the development of a model (see figure 1), illustrating the research inquiry of the practitioner's duality and paradoxes: the theoretical outsider who projects the bounded self based on the perspective of the world as influenced by priori theories, concepts, or constructs that potentially describe or explain certain phenomena. On the other hand, the practical insider's voice is projected through the unbounded self, one who views the world as it unfolds and is unrestrained by past conventions or conceptions. Simply put, the theoretical outsider views the world from top 
down through some prior understanding of theoretical construction, while the practical insider takes a more micro-process examination of the world from bottom up, represented by the base of the two inverted triangles in figure 1. Understanding the distinction between the two is crucial for transitioning from one position to another and integrating them in the holding space of research. As exemplified, research creates the space that holds the researcher's assumptions, understandings, emotions, and expectations of a particular context along with the perspectives of those living 'in' it. It is the inseparability of both positions that relates the life of research to the life of people which characterizes research as a dialogic and an intersubjective experience (Berger and Luckmann, 1966), the self-in-relation-to-others discourse that gives rise to thick description (Geertz, 1973).

===Insert Figure 1 near here===

\section{The bounded and unbounded selves}

The practitioner's motivation for conducting organizational research was largely influenced by Siggelkow's (2007) definition of worthy research, which is to enable the reader to see the world rather than the literature differently; therein lies the paradox of what the practical insider sees as organizationally emergent and the theoretical outsider regards as conceptually relevant. The paradox privileged the practitioner's interest in seeing the complementariness and contradictions between what his subjects said of their organizational world and their ensuing day-to-day actions. The relational approach to ethnographic fieldwork consequently enabled the practitioner to focus on the process of how elements of complementariness were developed and transitioned in contradictions. Reflecting on Sigglekow's (2007) worthy research made the practitioner realize that qualitative research is not merely about being aware of the interplay of the subjects' bounded and unbounded selves. Rather, it is about his personal connection and recognition of the complexity and vulnerability of the intertextual process, interplayed by the bounded (enacted) and unbounded (authentic) selves that 
enriched his research experience and gave rise to deeper understandings of relational influence of work practice (Cunliffe, 2010).

The bounded self or theoretical outsider's perspective of research tended to drive the practitioner's research paradigm according to commonsense knowledge or a priori theory (Islam, 2015). Such perspective could potentially narrow the practitioner's sensitivity towards what was already identified in the extant literature as logical conditions that governed particular behavioral patterns. For instance, the practitioner's commonsense knowledge of the cognitive and behavioral patterns of his colleagues was based on their enacted behavior projected on the surface of their daily interactions. However, as the practitioner interacted further with his colleagues, he was surprised to notice relational divergences from the perspective of what his subjects said they were going to do and their subsequent action or inaction. In this instance, the practitioner's bounded research orientation was challenged by a disruption or violation of his commonsense knowledge, which further pushed him towards framing his empirical observation as a tentative inquiry of what seemed like a complex but fascinating phenomenon unfolding in a complex context. The theoretical outsider decided to hold it as a hypothesis (empirical observation) rather than making immediate theorization of what he had encountered on the ground. It was at this juncture that the practical insider realized advancing theoretical knowledge too quickly would constrain what he could potentially explore more richly from the ground (Kegan, 1982). Subsequently, the practitioner decided to depart from a deeper search for theoretical insight at that point and instead learned to hold the emerging hypotheses as a burning research inquiry to be further explored through the practical insider lens, helping him formulate his research questions as knowledge gaps.

Thinking from the practical insider's perspective did not discount theoretical outsider's shadow, often his curiosity and instincts, which was very much a part of his prior 
conceptualization and sensemaking process when developing his research (Humphrey, 1924). Interactions with his colleagues further unleashed his unbounded self as he started relating to them through his personal voice while engaging in deeper conversations. Such relational experience intensified his sensitivity towards the transition of role boundaries where his subjects also began to relate with one another on different levels. For instance, not everyone operates with great spontaneity. There is the common holding back of opinions and concealment of identity. There is also the individual persona that might propel or inhibit him or her from engaging further due to personality clashes or other politicized influences.

The practitioner learned on many occasions to discard his bounded self in order to merge with others to harness a sense of otherness; that is, seeing the world through the eyes of others. Such merging unleashed his unbounded self to gain freedom and spontaneity in reconstructing his social world by establishing the structure of relations between himself and his subjects (Gergen, 2009). The following quotes between an informant and the practitioner exemplify the co-construction of social meanings where unbounded selves intersect:

Informant: I have no time for learning in this company [...] too many initiatives [...] I am skeptical of the change [that] is going on [...] I [have] stopped doing useless things $[\ldots]$ like filling up templates (for regular updates).

Practitioner: I feel the same [...] but we can't change 'change' [...] How do you feel about not doing the useless things?

Informant: I feel like [I'm] in control of things [...] feels good. Those templates box you in $[\ldots]$ I want to think out of the box!

Practitioner: What is it like without the boxes in your life? My boxes still give the space to work things out. They box me into focus. They make sense for me.

Informant: I see your point [...] I threw away my boxes but gave my input into someone's boxes (templates) by just talking and discussing things with them [...] and still get the job done.

In the above example, the practitioner spoke in a language with which those in the same context could resonate. They used "template" as a metaphor to suggest the tightly- 
framed work most of them were confined to. More importantly, further conversations with other colleagues revealed "stop doing" as a critical process of individual unlearning, an inaction that contributed to "input into someone's boxes" through "talking and discussing things", characteristic of collaborative learning (Hislop et al., 2014). The example reinforces the insider-outsider researcher paradox. Unless the theoretical outsider was in touch with a variety of emotions, perspectives, and actions relationally with his subjects, he would perhaps have to relentlessly hold his pseudo theory "as a hypothesis" without the possibility of a theoretical explanation. On the other hand, the practical insider would have the opportunity of inquiring more deeply into the phenomena by being immersed relationally with others until he "wakes up to the moment!" (see middle section of triangles in figure 1 indicating response to emerging knowledge). This is where the insider-outsider researcher capitalized on the paradox of his or her dual role to engage in the messy qualitative data and at the same time distil the richness of relational conditions under which complementariness and contradictions played out interdependently to derive some reasonable theoretical insight (Alvesson and Kärreman, 2007).

\section{Research as a holding space}

Viewing research from an insider-outsider perspective helped the practitioner appreciate research, including fieldwork and theorization, as a holding space for both himself and informants. Research creates a temporal space for organizational actors to transition between roles - as insiders and outsiders - and symbolically detach themselves from the expectations of their professional roles they assume at work (Van Buskirk and McGrath, 1999), so is the role of a practitioner researcher. The holding space served as an essential transitional passageway for both the practitioner and his collaborator to develop emerging relational turns in the critique of his data (see space adjoining the two triangles in figure 1). Reflective writing was the backbone of the holding space as the practitioner tried to make deeper sense 
of his role and data through the reimagining and reinterpretation of his raw data. This space facilitated the transition and integration of the duality by allowing distinct research motivations to intersect, indicated by the two overarching arrows in figure 1 . The holding space is also constituted of informants taking time out to share their personal stories or reflect on specific work issues is likened to a container of emotions, ideas, and meanings (Van Buskirk and McGrath, 1999). Often times, the interviews themselves became a holding space for the informants, including the practitioner, to discover themselves about what they felt or how they saw themselves in particular contexts (Kegan, 1982).

Relating the holding space to the bounded and unbounded selves, the paper recognizes that the ability to identify with self is a critical aspect of understanding human cognition and behavior (Fine, 1994), but often challenging as people tend to grapple with the interplay of insider and outsider personas (Gioia et al., 2010). For instance, when an informant said, "I am worth more than my work", the practitioner could sense that the employee was awarding himself a material value articulated in "worth". At the same time, the employee objectified "work" as sort of an entity competing with his sense of self represented by a tangible value. The theoretical-outsider position would intuitively theorize the quote as the informant expressing a motivational issue, but the practical-insider position would have seen things differently. The insider knowledge immediately knew the quote was an expression of frustration about abrupt change. In this example, the holding space represented by the conversation became the material aspect of participation for both the informant and the practitioner who became the container for his colleague by helping him contain his emotions, anxieties, and concerns.

The role of a theoretical-insider collaborator added yet another layer of interactional significance in the holding space. Asking "What are you holding or carrying when you said $[\ldots]$ in the reflective narratives?" opened the practitioner up to deeper thinking about his dual 
position and paradoxes. The theoretical insider was able to use his reflective writing as a resource to help transition the practitioner from the psychological passage of a theoretical outsider to that of a practical insider by, for instance, asking, "What do you see as change?" and "How can you change the situation?" The practitioner was not merely exploring the cognitive experience of others for the sake of theory development but rather engaging in reflecting how he could make a difference to his work and environment as a constituent of the workplace as well (Robertson, 2002). Often times, the theoretical-outsider position would be careful to reinforce a perspective down by first "holding it as a hypothesis" before further generalization, while the practical-insider position would "wake up to the moment", a response similar to situated knowing (Orlikowski, 2002) (see middle section of each triangle in figure 1). The holding space created relational possibilities wherein contextual dissecting and conceptual sensebreaking were deployed to not only allow the practitioner to hold his thoughts and emotions but also celebrate his paradoxical position as a researcher.

\section{Theory for practice versus practice for theory}

Many empirical studies aim to offer outcomes that will contribute to organizational practice through the development of theory for practice, suggesting that theoretical assumptions could be tested through practical applications (Wadham and Warren, 2014). While such practicebased research is moving in the right direction to bridge the theory-practice gap, far too few studies have considered an appropriate methodological approach to developing practice for theory (Islam, 2015). By practice for theory, the model suggests a focus on understanding real organizational phenomena without the influence of any theoretical assumptions or predictions. Simply put, practice in the form of actions, inter-actions, trans-actions, and activities (Dewey and Bentley, 1949) is governed by multiple knowledges that offer theoretical explanation giving rise to practice-based theory (Burawoy, 1998) or practice as theory becomes (Islam, 2015). Although consultancy-based research has long been regarded 
as driven by practice-for-theory inquiry, most studies still demonstrate theory-for-practice explanations through theoretical testing, validation, and/or elaboration (e.g. Gioia and Pitre, 1990; Ragin, 1987). This paper argues that the contribution towards practice for theory is the interrelation between critical knowledge and theoretical insights (see apex of each triangle in figure 1), generated through relational ethnographic fieldwork, involving both the practitioner and academic.

The practitioner's dual role certainly had a direct influence on his relationship with his subjects. In particular, the crafting and coproduction of knowledges took off at different starting points and on different relational levels. The practical insider's unbounded self yearned to be free of any potential biases to discover greater relational paradoxes, inconsistencies, and uncertainties where the starting point was to identify knowledge gaps from his own practice (see left triangle in figure 1). In contrast, the theoretical outsider's bounded self was guided by logical relationships of the world with which he associated as commonsense knowledge (see right triangle in figure 1). As data unfolded through the research process, the practitioner began to explore relational patterns that could explain certain complex relationships in more meaningful ways. In other words, the theoretical outsider was prone to exploring logical patterns that could be expressed in conceptual terms, while the practical insider delved more deeply into relational issues that stimulated him to question, contest, and seek alternative perspectives and solutions as he coproduced social meanings in his interaction with the subjects (Brown and Duguid, 1991).

The subtle yet critical shifts in the two roles transformed the practitioner's relationship with the informants interacting between direct and indirect participation (Habermas, 1987). The informants' voices were heard and captured on two levels: the voices of their bounded and unbounded personas. As the practitioner became more aware of the duality, he realized that his own bounded voice as a theoretical outsider would trigger a 
similar bounded response from an informant. If the practitioner perceived his organizational world through the lens of commonsense knowledge, he would potentially have constrained the potential and spontaneity for a wider variation of responses or voices from the informants based on the relational complexity (Wadham and Warren, 2014). Such constraints would also place a limit on the structure of their relationships restricting multi-voices to emerge. After all, the bounded view was satisfied by commonsense knowledge rather than a search for critical knowledge.

The practical insider would examine his relationship with his subjects further through critical thinking and role boundary expansion to determine how people view the world and how they act. Despite differences in research inquiry for the practical insider and theoretical outsider, theoretical insights were not developed through firmly-held hypotheses and neither was critical knowledge realized through situated knowing ("waking up to the moment!") (Handley et al., 2007). Instead, it was the interplay of organizing (construction of social meanings) and organization (structures and perceived realities of relationship) between the two positional paradoxes that gave rise to critical knowledge and theoretical insights, seen in the interaction between the two triangles in figure 1. It is the duality of the practitioner and the relational significance of a theoretical-insider collaborator that created the interplay of theory for practice and practice for theory, as he internalized (organizing) and externalized (organization) the reflexivity of found critiques in practice (Okhuysen and Bonardi, 2011). In particular, the theoretical insider, through recursive questioning and critique of his reflective narratives, helped him experience his paradoxical moments in the context of his data; after all, the practitioner was part of the data coproduction.

\section{RETHINKING RELATIONAL ETHNOGRAPHY IN ORGANIZATIONAL}

\section{RESEARCH}


Ethnographic methodology has been treated as a back-end activity as researchers study their objects of analysis as groups or places and determine how these are juxtaposed across contexts (Burawoy, 2017). In contrast, relational ethnography involves front-end analysis and critiques by focusing on interactional processes and spaces as basic objects of analysis (Desmond, 2014). Desmond (2014) offers a clue from which relational ethnography could be methodologically deployed in organizational research by treating a single organization as a field, where the profession of work practice is given multi-voiced representations by organizational actors as they enable or constrain work processes.

This paper argues for a more localized and micro-centric focus on the field of professional work practice rather than treating how fields of practice intersect across institutional contexts common in relational ethnography in sociological research. Further, this paper examines relational mechanisms through role positioning of both the researcher and subjects by juxtaposing insider-outsider roles to make sense of "how things hang together in a web of mutual influence or support or interdependence" (Becker, 1996; p. 56) rather than focusing on the contestation of knowledge categorizations and acknowledgment of theoretical divergences as potential objects of analysis in ethnographic research (Islam, 2015). The intermingling of insider-outsider roles, particularly of the researcher, is crucial for designing methodological strategies by “quite literally following connections, associations, and putative relationships" (Marcus 1998, p. 81), often times using storytelling as a distancing device to illuminate the object of the researched.

Reintroducing relational ethnography, which is "designed around chains, paths, threads, conjunctions" (Marcus 1998, p. 90) of social processes in organizations, offers crucial implications for qualitative research. Conducting qualitative research is not merely about finding an appropriate method but developing a methodology that is both flexible and open to innovation (Gioia et al., 2013). 
First, being aware of the bounded and unbounded selves will motivate researchers to delve more deeply into the discursive data coproduced by their informants from an inside-out and outside-in perspective. The positioning of researcher and subject roles is crucial in qualitative research as people occupying different positions are bound together in complementary and contradictory ways in a relationship manifesting mutual dependence or struggle (Desmond, 2014; Robertson, 2002). Being able to juxtapose between roles as practical insider and theoretical outsider could help the researcher grasp knowledge gaps in social practice and determine knowledge boundaries that "trigger further developments, new trains of thought, new events" (Klaver, 2004, p. 46) More importantly, it is the ability to rigorously identify and demonstrate connections between relational objects that theory and practice could be bridged to offer another dimension of qualitative methodology seen in organizational relational ethnography. This requires that researchers adapt, improvise, and develop innovative ways of data gathering and organizing (Corley, 2015; Glaser and Strauss, 1967).

Second, understanding the self-other connection and significance in relational ethnography transforms the researcher-informant relationship from predetermined expectations to an emergent quality (Hibbert et al., 2014). If researchers harness their duality of roles by both drawing closer to and distancing from the core of their research, they will create variations in agentic associations and ultimately influence their identities and actions, including their informants' (Gioia et al., 2010). The core of research is, therefore, no longer the boundary that narrows the scope of data but rather a space that holds mutual-implicating relationships between the researcher and researched (Suddaby, 2006), seen at the intersection between the insider and outsider roles in figure 1. Cunliffe and Karunanayake (2013) suggest that the intertextual relationship between the researcher and informant is situated in a hyphen space where boundaries between the researcher and researched are merged to reveal more of 
the underlying relational structures of the objects under study. Working the hyphen parallels the researcher juxtaposing the insider and outsider roles through a reflexive process of living 'in' and 'out' of a particular context (Fine, 1994).

Third, the paradoxical relationship between the insider and outsider does not push the researcher towards seeking differences in the interpretation of phenomena; rather, it creates a deeper awareness of the tension between subjectivity and objectivity (Eisenhardt, 1989). This is where the researcher finds balance in the holding space to account for the intersection between "holding it as a hypothesis" and "waking up to the moment" (see figure 1). After all, keeping close to authentic data by actively coproducing it helps keep the researcher honest (Eisenhardt and Graebner, 2007). Relational ethnography holds that the researcher enters the holding space of research by putting on the practice lens to critique emerging theory and constructing the context with their subjects at the same time. If both the researcher and informants recognize their unbounded selves, they could search deep into their own true voices to project their view of their external (organizational) world (Gergen, 2009).

The question of generalizability remains a point of contention for qualitative researchers (Guba and Lincoln, 1994; Yin, 1981). Relational ethnography offers real-time data from multi-voiced perspectives within a practice field offering the practical insider insights that can be translated into concrete terms for managerial practice (c.f. Corley, 2015; Siggelkow, 2007). Arguably, the researcher lives 'in' the actual experiences of others in a social context that allows him or her to make deeper sense of emerging structures of relations in processes, systems, people, and practices offering a more sustainable representation of data (Gioia et al., 2013).

TOWARDS RELATIONAL EXPERIENCE IN QUALITATIVE RESEARCH 
This paper built on the premise that practice, in some form, is what theory becomes when critiqued and analyzed through different interpretations and positions of interest (Islam, 2015). It developed a relational perspective of qualitative research by emphasizing the criticality of the practitioner-researcher role as both a practical insider and a theoretical outsider. It extended current understanding of ethnographic research by arguing that reflexivity is deeply harnessed in the holding space of research. The researcher gains insight from being relationally-significant to the subjects and at the same time relating rich (practical) experiences to gain theoretical insight from a theoretical insider, usually the collaborator. The relational way of bridging theory and practice through such collaboration is rare and should be encouraged (Cunliffe and Locke, 2015). The reference point for introducing relational ethnography in organizational research stems from the living experience of the first author where he round living 'in' and 'out' of a context is critical to experiencing the underlying structures of relations of the researched. Being part of real-time data is also a step closer to coproducing authentic data in relational ethnography not tainted by politicized voices in the field of professional practice.

The paper further argued that the holding space of research is where relational ethnographers both internalize and externalize their reflexivity of what is going on in a context through the juxtaposition of their insider-outsider selves helping, in turn, unleash the unbounded selves of their subjects. Unbounded selves project individual and potentially genuine voices unconstrained by tradition or past understanding. In order to unleash the unbounded selves of others, relational ethnographers first take on the identity of practical insiders as one of us in order to bodily experience the lives of others (Martin, 2002). The research process becomes the holding space for relational ethnographers to bodily immerse themselves in the experience of others. Subsequently, the holding space becomes the locus of philosophical tensions between the insider-and-outsider methodological orientation, 
transposing commonsense knowledge to critical knowledge (Zilber, 2002). Negotiating the paradox is a critical aspect of relational ethnography, where the researcher mediates between the abstract and concrete, perception and reality, as well as subjective understanding and objective evaluation. Relational ethnography seeks to better understand and relate to the social world rather than conducting research as a self-referential activity telling others what the world is and is not (Siggelkow, 2007).

Conducting relational ethnographic research is not without its challenges and limitations. The drawing near to and distancing from the data requires practice; it is not a logical response to methodological requirements but rather a relational craft (Cunliffe and Locke, 2015). First, although power distance did not necessarily interfere with the relational significance between the practitioner and his informants of higher hierarchical positions, it sometimes created biases when sensitive information was released. For instance, phrases like "just between you and me", "for your ears only", "keep this confidential", "you are the only one who knows this", and so on did influence the practitioner in the way he interpreted the information and structures of meanings in their conversations. The fine line between the practitioner and his colleagues was often difficult to demarcate and this inadvertently affected the manner in which mutual identities and narratives were constructed (Gioia et al., 2010). Second, being privy to sensitive information - which could increase the knowledgeability of the practitioner (Gioia et al., 2013) - hinges on questions of ethicality. Rather than helping the practitioner gain entry into unique real-time data, playing dual roles in effect hindered deeper connections, particularly so when informants were unclear if their interaction with the practitioner was used as a basis for data analysis. The practitioner was constantly mindful of the question: "How far and deep should I go into to gain insight?" Zooming in and out between insider and outsider positions sometimes led to the practitioner treating his colleagues as subjects and objects, although the object of relational ethnography was not 
necessarily people or places (Desmond, 2014). Often times, this dilemma raised the question of morality (Stanley and Wise, 1990). If relational ethnography is about engaging informants as real people, researchers will have to be responsible for their involvement and the data they coproduce. Negotiating between research subjectivity and objectivity, therefore, requires delicate balance, as is playing the dual role as a researcher.

Future research could extend exploration of the paradoxes of qualitative researchers, particularly their response to their research process and the researched. The much-needed research collaboration between practitioners and academics, and how their interaction unfolds in the holding space of research is also worth exploring. In particular, it might be interesting to explore the duality of the researcher from the psychodynamic perspective of how the researcher reconciles the different facets of lived experience as he or she participates in between transitory spaces of relational configurations (c.f. Petriglieri and Petriglieri, 2010; Winnicott, 1986). A deeper exploration is perhaps needed for incorporating relational ethnography as part of the methodological repertoire of qualitative research by focusing on organizations as fields of professional practice. As contemporary organizations go in the direction of virtual and project teams, fields of professional practice have become the point of interest for qualitative researchers to study the coordination and distribution of work in multiple configurations of relations (c.f. Bechky, 2003). Building on Cunliffe and Locke's (2015) call for community building in qualitative research, it is worthwhile to revisit the relational significance of collaborations between practitioners and academics by exploring how practical and theoretical voices intersect, and how theorization is established through the joint imagination of pseudo theory (c.f. Islam, 2015). As a caveat, although practitionerresearchers are privileged to live 'in' the context of research, they should recognize that they could inevitably be lost in the thick of their fieldwork. They should always be prepared to celebrate their paradoxes when living in between the holding space of their insider and 
outsider selves (Fine, 1994). Sometimes, getting lost in the multi-voiced contexts is the only way for the true, authentic voice to be found.

\section{REFERENCES}

Alvesson, M. and Kärreman, D. (2007), “Constructing mystery: empirical matters in theory development", Academy of Management Review, Vol. 32 No. 4, pp. 1265-1281.

Azmatullah, S. (2014). The coach's mind manual: Enhancing coaching practice with neuroscience, psychology and mindfulness, Routledge, London.

Bakhtin, M. M. (1981), The dialogic imagination: Four essays by M. M. Bakhtin, University of Texas Press, Austin, TX.

Becker, H. (1996). “The epistemology of qualitative research”, in R. Jessor, A. Colby, and R. Shweder (eds.), Ethnography and human development: Context and meaning in social inquiry (pp. 53-72). University of Chicago Press. Chicago, IL.

Bechky, B. A. (2003). "Sharing meaning across occupational communities: The transformation of understanding on a production floor", Organization Science, Vol. 14 No. 3, pp. 312-330.

Berger, P. L. and Luckmann, T. (1966), The social construction of reality: A treatise in the sociology of knowledge, Anchor Books, Doubleday, New York, NY.

Bogdan, R. C. and Biklen, S. K. (1992). Qualitative research for evaluation (2 ${ }^{\text {nd }}$ Ed.), Allyn \& Bacon, Needham Heights, MA,

Boltanski, L. (2011). On critique: A sociology of emancipation, Polity, Cambridge, UK.

Brown, P. S. and Duguid, P. (1991). "Organizational learning and communities-of-practice:

Toward a unified view of working, learning, and innovating”, Organization Science, Vol. 2 No. 1, pp. 40-58. 
Burawoy, M. (1998). “The extended case method”, Sociological Theory, Vol. 16 No. 1, pp. 4-33.

Burawoy, M. (2017). “On Desmond: The limits of spontaneous sociology”, Theory and Society, Vol. 46 No. 1, pp. 261-284.

Clark, A. M. and Sousa, B. J. (2017), “The five neglected skills all qualitative researchers need”, International Journal of Qualitative Methods, Vol. 16 No. 1, pp. 1-3.

Clegg, S. R., Kornberger, M. and Rhodes, C. (2005), "Learning/becoming/organizing”, Organization, Vol. 12 No. 2, pp. 147-167.

Corley, K. G. (2015), “A commentary on "What grounded theory is...”: Engaging a phenomenon from the perspective of those living in it", Organizational Research Methods, Vol. 18 No. 4, pp. 600-605.

Cunliffe, A. L. (2010), "Retelling tales of the field in search of organizational ethnography 20 years on”, Organizational Research Methods, Vol. 13 No. 2, pp. 224-239.

Cunliffe, A. L. and Karunanayake, G. (2014), "Working within hyphen-spaces in ethnographic research: Implications for research identities and practice”, Organizational Research Methods, Vol. 16 No. 3, pp. 364-392.

Cunliffe, A. L. and Locke, K. (2015), "Continuing to build community in qualitative research", Qualitative Research in Organizations and Management, Vol. 10 No. 4, pp. $310-313$.

Desmond, M. (2014), "Relational ethnography”, Theory and Society, Vol. 43 No. 1, pp. 547579.

Dewey, J. and Bentley, A. F. (1949), Knowing and the known, Beacon Press, New York, NY. Eisenhardt, K. M. (1989), “Building theories from case study research”, Academy of Management Review, Vol. 14 No. 4, pp. 532-550. 
Eisenhardt, K. M. and Graebner, M. E. (2007), “Theory building from cases: Opportunities and challenges", Academy of Management Journal, Vol. 50 No. 1, pp. 25-32.

Fawcett, B. and Hearn, J. (2004), "Researching others: Epistemology, experience, standpoints and participation", International Journal of Social Research Methodology, Vol. 7 No. 3, 201-218.

Fine, M. (1994), "Working the hyphens: Reinventing self and other in qualitative research", in Denzin N. K. and Y. S. Lincoln (Eds.), Handbook of qualitative research, Sage: Thousand Oaks, CA, Sage, pp. 70-82.

Gergen, K. J. (2009), Relational being: Beyond self and community, Oxford University Press, New York, NY.

Gergen, K. J. and Gergen, M. (2002), "Ethnography as relationship”, in Bochner, A. and Ellis, C. (Eds.), Ethnographically speaking. Autoethnography, literature, and aesthetics, Alta Mira Press, Walnut Creek, CA, pp.11-33.

Geertz, C. (1973), The interpretation of cultures, Basic Books, New York, NY.

Gioia, D. A. and Chittipeddi, K. (1991), "Sensemaking and sensegiving in strategic change initiation", Strategic Management Journal, Vol. 12 No. 6, pp. 433-448.

Gioia, D. A. and Pitre, E. (1990), "Multiparadigm perspectives on theory building”, Academy of Management Review, Vol. 15 No. 4, pp. 584-602.

Gioia, D. A., Corley, K. G. and Hamilton A. L. (2013), “Seeking qualitative rigor in inductive research: Notes on Gioia methodology", Organizational Research Methods, Vol. 16 No. 1, pp. 15-31.

Gioia, D. A., Price, K. N., Hamilton, A. L. and Thomas, J. B. (2010), "Forging an identity: An insider-outsider study of processes involved in the formation of organizational identity", Administrative Science Quarterly, Vol. 55 No. 1, pp. 1-46. 
Glaser, B. G. and Strauss, A. L. (1967), The discovery of grounded theory: Strategies for qualitative research, Aldine, New York, NY.

Guba, E. G. and Lincoln, Y. S. (1994), “Competing paradigms in qualitative research”, in Denzin, N. and Lincoln, Y. (Eds.), Handbook of qualitative research, Sage, Thousand Oaks, CA, pp. 105-117.

Habermas, J. (1987), The theory of communicative action (Vol. 2): Lifeworld and system, Beacon, Boston, MA.

Handley, K., Clark, T., Fincham, R. and Sturdy A. (2007), "Researching situated learning: Participation, identity and practices in client-consultant relationships", Management Learning, Vol. 38 No. 2, pp. 173-191.

Hibbert, P., Sillince, J., Diefenbach, T. and Cunliffe, A. L. (2014), "Relationally reflexive practice: A generative approach to theory development in qualitative research", Organizational Research Methods, Vol. 17 No. 3, pp. 278-298.

Hislop, D., Bosley, S., Coombs, C. R. and Holland, J. (2014), “The process of individual unlearning: A neglected topic in an under-researched field", Management Learning, Vol. 45 No. 5 , pp. 540-560.

Humphrey, G. (1924), “The psychology of the gestalt”, Journal of Educational Psychology, Vol. 15 No. 7, pp. 401-412.

Islam, G. (2015), "Practitioners as theorists: Para-ethnography and the collaborative study of contemporary organizations”, Organizational Research Methods, Vol. 18 No. 2, pp. 231251.

Klaver, I. (2004). "Boundary projects versus border patrol”, in Foltz, B. and Frodeman, R. (Eds.), Rethinking nature: Essays in environmental philosophy, Indiana University Press, Bloomington, IN, pp. 44-55. 
Kegan, R. (1982), The evolving self: Problems and processes in human development, Harvard University Press, Cambridge, MA.

Kempster, S. and Stewart, J. (2010), “Becoming a leader: A co-produced autoethnographic exploration of situated learning of leadership practice", Management Learning, Vol. 41 No. 2, pp. 205-219.

Marcus, G. (1998), Ethnography through thick and thin. Princeton University Press, Princeton, NJ.

Martin, P. Y. (2002), "Sensations, bodies, and the "spirit of a place": Aesthetics in residential organizations for the elderly”, Human Relations, Vol. 55 No. 7, pp. 861-885.

Okhuysen, G. and Bonardi, J-P. (2011), “Editors' comments: The challenges of building theory by combining lenses". Academy of Management Review, Vol. 36 No. 1, pp. 6-11.

Orlikowski, W. J. (2002), "Knowing in practice: Enacting a collective capability in distributed organizing”, Organization Science, Vol.13 No. 3, pp. 248-273.

Petriglieri, G. and Petriglieri, J. L. (2010), “Identity workspaces: The case of business schools", Academy of Management Learning and Education, Vol. 9 No. 1, pp. 44-80.

Ragin, C. C. (1987), The comparative method: Moving beyond qualitative and quantitative strategies, University of California Press, Berkeley, CA.

Robertson, J. (2002), "Reflexivity redux: A pithy polemic on 'positionality”,, Anthropological Quarterly, Vol. 75 No. 4, pp. 785-792.

Siggelkow, N. (2007), "Persuasion with case studies", Academy of Management Journal, Vol. 50 No. 1, pp. 20-24.

Simon, G. (2012), "Relational ethnography: Writing and reading in research relationships [44 paragraphs]". Forum Qualitative Sozialforschung / Forum: Qualitative Social Research, 14(1), Art. 4, [ http://nbn-resolving.de/urn:nbn:de:0114-fqs130147] 
Stainback, S. and Stainback, W. (1988), Understanding and conducting qualitative research, Kendall-Hunt, Iowa, IA.

Suddaby, R. (2006), "What grounded theory is not", Academy of Management Journal, Vol. 49 No. 4, pp. 643-642.

Trist, E. L. and Bamforth, K. W. (1951), "Some social and psychological consequences of the longwall method of coal-getting”, Human Relations, Vol. 4 No. 3, pp. 3-38.

Van Buskirk, W. and McGrath, D. (1999), “Organizational cultures as holding environments: A psychodynamic look at organizational symbolism”, Human Relations, Vol. 52 No. 6, pp. $805-832$.

Van Maanen, J. (1979), “The fact of fiction in organizational ethnography”, Administrative Science Quarterly, Vol. 24 No. 4, pp. 539-550.

Wadham, H. and Warren, R. C. (2014), “Telling organizational tales: The extended case method in practice", Organizational Research Methods, Vol. 17 No. 1, pp. 5-22.

Weber, F., Nice, R., and Wacquant, L. (2001), Settings, interactions and things: A plea for multi-integrative ethnography, Ethnography, Vol. 2 No. 4, pp. 475-499.

Weick, K. E., Sutcliffe, K. M. and Obstfeld, D. (2005), “Organizing and the process of sensemaking”, Organization Science, Vol. 16 No. 4, pp. 409-421.

Winnicott, D.W. (1986), Home is where we start from, W.W. Norton, New York, NY.

Yin, R. K. (1981), “The case study crisis: Some answers”, Administrative Science Quarterly, Vol. 26 No. 1, pp. 58-65.

Zilber, T. B. (2002), "Institutionalization as an interplay between actions, meanings and actors: The case of a rape crisis center in Israel", Academy of Management Journal, Vol. 45 No. 1, pp. 234-254. 
Table I: The Insider-Outsider Paradoxes

\begin{tabular}{|c|c|c|c|}
\hline Phase & $\begin{array}{c}\text { Bounded Self } \\
\text { (Theoretical Outsider) }\end{array}$ & $\begin{array}{l}\text { Unbounded Self } \\
\text { (Practical Insider) }\end{array}$ & Researcher's Paradox \\
\hline $\begin{array}{l}\text { Entry } \\
\text { Prior Knowledge }\end{array}$ & $\begin{array}{l}\text { Viewing the social world as } \\
\text { constructed by the } \\
\text { preconception of others } \\
\text { based on what has been said } \\
\text { and written about. } \\
\text { Feeling like everyone else in } \\
\text { the workplace. } \\
\text { Accepting certain behaviour } \\
\text { as expected norm. } \\
\text { Being cautious of not over- } \\
\text { pushing boundaries to learn } \\
\text { about others' thinking and } \\
\text { behaviour. } \\
\text { Remaining in a safe zone. }\end{array}$ & $\begin{array}{l}\text { Viewing the social world in } \\
\text { relation to the unfolding of } \\
\text { activities and happenings in } \\
\text { real time. } \\
\text { Seeing everyone as } \\
\text { individuals with a personal } \\
\text { voice. } \\
\text { Recognizing others' } \\
\text { struggles with identity and } \\
\text { belonging. } \\
\text { Being spontaneous to the } \\
\text { nuances of others. } \\
\text { Pushing relational } \\
\text { boundaries to understand } \\
\text { their inner thoughts and } \\
\text { feelings. }\end{array}$ & $\begin{array}{l}\text { Negotiating between } \\
\text { identity versus belonging. } \\
\text { Not compromising on } \\
\text { personal identity and } \\
\text { values while interacting } \\
\text { with others. } \\
\text { Seeking acceptance by } \\
\text { identifying with general } \\
\text { sentiments. } \\
\text { Trying to reconcile } \\
\text { perceived behaviour and } \\
\text { authentic behaviour. }\end{array}$ \\
\hline $\begin{array}{l}\text { Transition } \\
\text { Data Gathering } \\
\text { (interviewing, } \\
\text { interaction and } \\
\text { observation) }\end{array}$ & $\begin{array}{l}\text { Reinforcing or rejecting } \\
\text { preconceived reality by } \\
\text { developing a story about } \\
\text { whether people fit or do not } \\
\text { fit into certain expectations } \\
\text { or assumptions of the } \\
\text { majority. } \\
\text { Wearing the hat of a } \\
\text { stranger to reconnect with } \\
\text { people and context. } \\
\text { Identifying both positive } \\
\text { and negative views about a } \\
\text { particular context. } \\
\text { Synchronizing views that } \\
\text { become dominant in a } \\
\text { particular context. } \\
\text { Holding back judgement } \\
\text { about others' assumption of } \\
\text { their immediate context. }\end{array}$ & $\begin{array}{l}\text { Being spontaneous to } \\
\text { discover, curious to inquire, } \\
\text { and courageous to challenge } \\
\text { the deeper thoughts and } \\
\text { views of others and the } \\
\text { researcher himself. } \\
\text { Establishing some level of } \\
\text { vulnerability with others in } \\
\text { order to open them up to } \\
\text { deeper conversations. } \\
\text { Empathizing with others for } \\
\text { situations that can be } \\
\text { identified on a personal } \\
\text { level. } \\
\text { Helping others make sense } \\
\text { of their dilemmas. } \\
\text { Listening to the deeper } \\
\text { voice of others by being a } \\
\text { connecting tissue or } \\
\text { sounding board. }\end{array}$ & $\begin{array}{l}\text { Negotiating between } \\
\text { control and connection. } \\
\text { Exercising discipline and } \\
\text { spontaneity in learning } \\
\text { about others. } \\
\text { Trying to be free from the } \\
\text { control of shared } \\
\text { expectations of others' } \\
\text { behavior in a particular } \\
\text { context. } \\
\text { Struggling to find a } \\
\text { middle ground to connect } \\
\text { with others in order to } \\
\text { learn about how they } \\
\text { think, feel, and act. }\end{array}$ \\
\hline $\begin{array}{l}\text { Exit } \\
\text { Reflective } \\
\text { Sensemaking }\end{array}$ & $\begin{array}{l}\text { Interpreting the reality } \\
\text { based on how people make } \\
\text { sense of their social world } \\
\text { by identifying the } \\
\text { relationship between their } \\
\text { perceived and lived } \\
\text { experience. } \\
\text { Using stories of others as } \\
\text { boundary objects to learn } \\
\text { about expected thinking and }\end{array}$ & $\begin{array}{l}\text { Interpreting the reality } \\
\text { based on how people make } \\
\text { sense of their inner and } \\
\text { social world by identifying } \\
\text { the relationship between } \\
\text { their desired and lived } \\
\text { experience. } \\
\text { Being sensitive to different } \\
\text { expectations of individuals } \\
\text { and work. }\end{array}$ & $\begin{array}{l}\text { Negotiating between } \\
\text { reliance and autonomy. } \\
\text { Identifying similarities } \\
\text { and differences between } \\
\text { individual behaviours. } \\
\text { Relying on preconceived } \\
\text { understanding of } \\
\text { particular behaviour to } \\
\text { make sense of data. }\end{array}$ \\
\hline
\end{tabular}




\begin{tabular}{|l|l|l|l|}
\hline & $\begin{array}{l}\text { behaviour. } \\
\text { Refining the contextual } \\
\text { boundaries of how an } \\
\text { organization is perceived. }\end{array}$ & $\begin{array}{l}\text { Reconnecting with each } \\
\text { other as individuals rather } \\
\text { than a collective unit. }\end{array}$ & $\begin{array}{l}\text { Finding a delicate balance } \\
\text { between recognizing } \\
\text { others' enacted behaviour } \\
\text { and appreciating their } \\
\text { authentic behaviour. } \\
\text { of self-worth and personal } \\
\text { values associated with a } \\
\text { particular context. } \\
\text { the image of an } \\
\text { organization. }\end{array}$ \\
$\begin{array}{l}\text { Recognizing underlying } \\
\text { assumptions that have not } \\
\text { been challenged. }\end{array}$ & $\begin{array}{l}\text { Recognizing the disparity } \\
\text { between projected voice and } \\
\text { authentic voice through } \\
\text { deeper interaction. }\end{array}$ & \\
\hline
\end{tabular}


Table II: Collaborative Sensemaking between Practitioner and Academic

\begin{tabular}{|c|c|c|}
\hline Researcher's Paradox & Relational Considerations & Methodological Implications \\
\hline $\begin{array}{l}\text { Identity versus } \\
\text { belonging }\end{array}$ & $\begin{array}{l}\text { Practical insider: } \\
\text { - } \quad \text { Using distinct voice to earn respect } \\
\text { from others. } \\
\text { - Capitalizing on position of } \\
\text { influence to connect and relate } \\
\text { with others. } \\
\text { Theoretical outsider: } \\
\text { Developing a relationship with the } \\
\text { data through reflective writing. } \\
\text { Engaging in deep conversations } \\
\text { with a theoretical insider to } \\
\text { understand the data at a different } \\
\text { level. }\end{array}$ & $\begin{array}{l}\text { Refining research issues: } \\
\text { - Ground research in the interest } \\
\text { (how they feel) rather than the } \\
\text { position (what they say) of the } \\
\text { subjects. } \\
\text { Internalizing real-time data: } \\
\text { - Rewrite qualitative data into } \\
\text { narratives as a reflective } \\
\text { process. } \\
\text { Gaining data insights: } \\
\text { Create value of the data by } \\
\text { collaborating with an academic } \\
\text { to understand the interest } \\
\text { (authentic voice) and position } \\
\text { (enacted voice) of the data } \\
\text { better. }\end{array}$ \\
\hline $\begin{array}{l}\text { Control versus } \\
\text { connection }\end{array}$ & $\begin{array}{l}\text { Practical insider: } \\
\text { - Making a difference by helping } \\
\text { others make sense of who they are } \\
\text { and how they can make a } \\
\text { difference. } \\
\text { Looking beyond the surface of } \\
\text { things to identify underlying } \\
\text { emotional and behavioral nuances. } \\
\text { Theoretical outsider: } \\
\text { Developing a relationship with the } \\
\text { research process by documenting } \\
\text { specific moments of opportunities } \\
\text { and constraints to clarify } \\
\text { contextual issues. } \\
\text { Inviting inquiry and feedback on } \\
\text { the documented narratives to } \\
\text { unlock assumptions of data } \\
\text { interpretation. }\end{array}$ & $\begin{array}{l}\text { Understanding contextual dissecting: } \\
\text { - } \text { Internalize data based on the } \\
\text { practitioner's firsthand } \\
\text { experience to identify the } \\
\text { genuine and enacted self. } \\
\text { Shifting vantage point of the social } \\
\text { world: } \\
\text { - Use reflective essays as } \\
\text { boundary objects and invite the } \\
\text { collaborator (academic) to co- } \\
\text { construct the discourse by } \\
\text { developing a richer description } \\
\text { of the phenomena under study. }\end{array}$ \\
\hline $\begin{array}{l}\text { Reliance versus } \\
\text { autonomy }\end{array}$ & $\begin{array}{l}\text { Practical insider: } \\
\text { - } \quad \text { Noticing others' discomfort in a } \\
\text { particular context to learn about } \\
\text { the other side of their behaviour. } \\
\text { - } \quad \text { Being aware of how people see } \\
\text { themselves and how others see } \\
\text { them creates a different dynamic of } \\
\text { connection. } \\
\text { Theoretical outsider: } \\
\text { Refining understanding of data } \\
\text { through ongoing reflective writing } \\
\text { to find new meaning in the data. } \\
\text { Indulging in ongoing conversations } \\
\text { with a theoretical insider to } \\
\text { internalize data at a deeper level. }\end{array}$ & $\begin{array}{l}\text { Using sharp questioning: } \\
\text { Develop a relational } \\
\text { experience between the } \\
\text { practitioner and academic } \\
\text { where both could discuss each } \\
\text { other's understanding of the } \\
\text { data. } \\
\text { Using sensebreaking techniques: } \\
\text { - Deploy 'what if' technique to } \\
\text { challenge assumptions about } \\
\text { the data to justify contextual } \\
\text { explanation and understand } \\
\text { theoretical implications. }\end{array}$ \\
\hline
\end{tabular}


Figure 1: The Insider-Outsider Research Inquiry

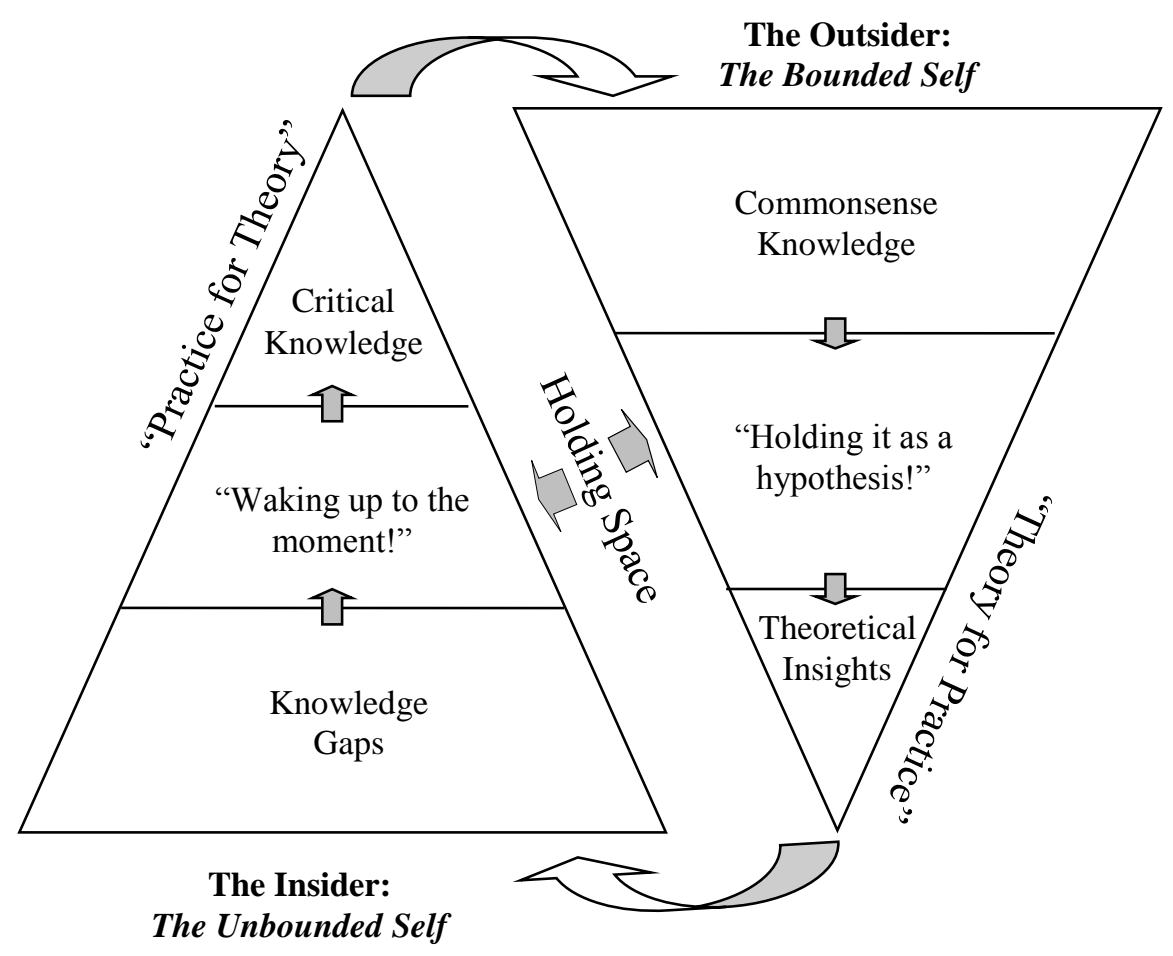

